\title{
Distribution and Relative Abundance of Anchovies (Clupeiformes-Engraulididae) in the Sepetiba Bay, Rio de Janeiro, Brazil
}

\author{
Márcio de Araújo Silva* and Francisco Gerson de Araújo \\ Universidade Federal Rural do Rio de Janeiro, Posto de Aqüicultura, Lab. de Ecologia de Peixes \\ Km 47 Antiga Rodovia Rio - São Paulo, 23.851-970 Seropédica - RJ, Brazil
}

\begin{abstract}
Distribution and relative abundance of juvenile fish of the family Engraulididae in the Sepetiba Bay, Rio de Janeiro, Brazil was assessed to detect patterns of use of the shallows during their early life cycle. Two yearly cycle (March1996 to February-1997 and March-1997 to February-1998) were studied by a total of 120 beach net samples at five sites, two of them located in the inner Bay and three in the outer Bay near to the sea limit. Six Engraulididae species were identified in two genera: Anchoa januaria, Anchoa marinii, Anchoa tricolor, Anchoa lyolepis, Anchoviella lepidentostole and Anchoviella brevirostris, mainly juveniles in their early life cycle. A. januaria, A. brevirostris, A. lepidentostole and A. tricolor, in decreasing order, were the top numerical abundant species, while A. tricolor and A. januaria showed the highest weight contribution, amounting approximately to $90 \%$ of the total number of fish. Spatially, A. tricolor, A. lyolepis and A. marinii distributed mainly in the outer Bay. A. januaria show higher abundance in the inner Bay, while the species of genera Anchoviella show an ample distribution, without a particular zone of higher occurrence. Seasonally, only A. januaria, A. lepidentostole and A. brevirostris presented a clear pattern of occurrence, peaking in the Autumn.
\end{abstract}

Key words: Engraulididae, anchoa, anchoviella, anchovy, Sepetiba Bay

\section{INTRODUCTION}

Fishes of the family Engraulididae are very abundant in coastal regions which are used as rearing and early life development. They spawn in coastal zones and their eggs and larval phases enter estuaries and bays where they find protection and food availability (Coto et al., 1988; Macgregor \& Houde, 1996).

Anchovies, as they are known, are pelagic fishes, which concentrate in large shoaling making them object of heavy fisheries. In 1972, only in Peru twelve million ton were recorded in anchovies fisheries, which amounted to $22 \%$ of the world catches, mainly of Engraulis rigens (Valentin, 1994). According to Whitehead (1977) 2076 tons of Engraulididae were caught in the Western Central Atlantic in 1975, mainly in Venezuela, with Cetengraulis edentulus (Curvier, 1829) contributing to about $70 \%$ of the total fisheries. In Brazil, anchovy fisheries are very common in estuaries and lower reaches of river Ribeira do Iguape and São Vicente, São Paulo State, mainly on Anchoviella lepidentostole, the only genera which shows eurihaline adaptation, moving in lower reaches of rivers for spawning (Bendazoli et al.,1990; Paiva-Filho et al., 1986; 1990). In Paraíba do Sul river, intensive catch of Anchoviella lepidentostole takes place near to São Fidelis town (Araújo, 1996). The main use of achovies is as canned fish, oils and flour, besides bait. This fish play an important ecological role in the ocean food web, as prey for many species and birds (Hildebrand, 1963). Sepetiba Bay is considered an important coastal marine area in Rio de Janeiro State, presenting a considerable amount of organic input in suspension, dissolved salts and high concentration of planctonic algae which made their waters suitable for rearing of many marine species (Araújo, 1997).

Mechanisms of spatial repartition in estuaries and coastal lagoon areas in part of strategy for keeping

\footnotetext{
* Author for correspondence
} 
their high numbers and coexist during early life cycle (Moermond, 1979) and habitat segregation is one of the most important way to their ecology. Seasonality of Engraulididae in Sepetiba Bay was studied by Sergipense \& Sazima (1995). The goal of this work is to describe pattern of distribution and relative abundance of the six species of anchovies aiming to contribute to the knowledge of ecology of those fishes in the Sepetiba Bay.

Study area: Sepetiba Bay (Fig. 1) is located in the southern of Rio de Janeiro State (22 $54^{\prime} 2^{\circ} 04^{\circ}$ 'S and $43^{\circ} 34^{\prime} 44^{\circ} 10^{\prime} \mathrm{W}$ ), showing a elongated form bordering at North and East by the continental margin, at South by the Marambaia sandbank, at West by Ilha Grande Bay. Its length is about 43 $\mathrm{Km}$ in the East-West direction and its width is about $17 \mathrm{Km}$ in North-South direction, with perimeter of approximately $123 \mathrm{Km}$. The watershed shows an area of $1800 \mathrm{Km}$.

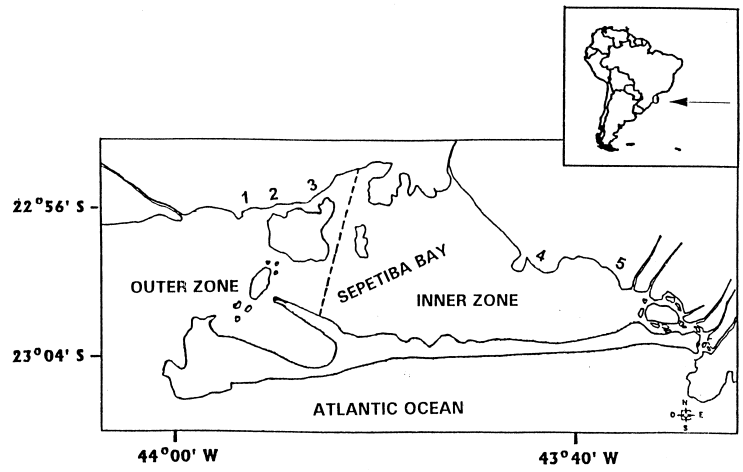

Scale 1: 425.000 .

Figure 1. Study Area - Sepetiba Bay, Rio de Janeiro, Brazil, with indications of the 5 sampling stations.

A unique feature of Sepetiba Bay is the Marambaia sankbank which join the Marambaia Isle to the continent, showing a linear formation parallel to continent shoreline, formed basically by sand sediment, constituting a large protection of the Bay from the ocean waters.

The Station 1 (Fig. 1) had a sandy mud bottom and was close to the sea limit. Station 2 had a shelly mud substrate and Station 3 had a sandy bottom located within a protected area of the outer Bay. Station 4 had a shelly mud substrate and was representative of the central, internal part of the Bay, whilst the innermost Station 5 had a heavy mud bottom. Overall the outer stations 1-3 had moderately organic substrates and inner Bay stations 4-5, had highly organics muddy bottoms. Salinity was stable and high, ranging from 26 to $32 \%$, during most of the year, with a slight increasing gradient from the inner to the outer Bay (Araújo et al., 1998). The lowest records of salinity were limited to the mouth of small rivers with emphasis to Guandu river, the most freshwater contribution to the Bay. Temperature in the region is typical for sub-tropical zones, with minimal averages of $21^{\circ} \mathrm{C}$ and maximum of $30^{\circ} \mathrm{C}$ (Barbieri \& Kronemberg, 1994) near to the shallows and continental zones. Substrate is predominantly muddy in the inner Bay and sandmuddy and gravel in the outer Bay.

\section{MATERIALS AND METHODS}

Fishes were collected monthly at five stations in the continental margin of Sepetiba Bay (Fig 1) March 1996 and February 1998, which differed in location and substrates. Sampling procedure started early in the morning and finished at sunset. A total of 120 samples (5 sites x 24 months) were carried out. Fishes were collected with a beach seine $10 \mathrm{~m} \times 2 \mathrm{~m}$ and $5 \mathrm{~mm}$ mesh. On each occasion the net was pulled far about $50 \mathrm{~m}$ parallel to the shore covering an area of $500 \mathrm{~m}^{2}$ in water up to $1 \mathrm{~m}$ in depth. This procedure was replicated twice at each sampling site. Fishes were preserved in $10 \%$ formaldehyde and subsequently identified to species and counted. Individuals were measured for total length (TL), and then the total weight of the pooled sample of each species was taken. All counted and weighted; identification followed Figueredo \& Menezes (1978). Depth was measured on every sampling visit.

A three-way ANOVA (Model I; $p<0.05$ ) was used to determine whether the densities (individuals $/ 500 \mathrm{~m}^{2}$ ) of the six species differed between stations, seasons and year. Seasons were defined as Winter: July and August; Spring: September, October and November; Summer: December, January and February; and Autumn: March, April and May. For the purposes of the study, data from samples taken in each of the three months representing a quarterly season were taken as replicates for the ANOVA analyses. Raw abundance data were $\log _{10}(\mathrm{x}+1)$ transformed to fulfil the homoscedasticity and normality requirements for ANOVA. The Student-NewmanKeuls - SNK's multiple range test was used to determine differences in mean values following ANOVA. 


\section{RESULTS}

Composition and abundance: Among a total of 2606 fishes recorded in 120 samples, anchovies amounted $2336.1 \mathrm{~g}$ being $38.2 \%$ by number and $67.1 \%$ by weight in the first year of sampling, and $61.8 \%$ by number and $32.9 \%$ by weight in the second year, respectively. The six species found in Sepetiba Bay were in order of decreasing numerical abundance: Anchoa januaria, Anchoviella brevirostris, Anchoviella lepidentostole, Anchoa tricolor, Anchoa marini and Anchoa lyolepis. A. januaria was the most abundant species among these, contributing to $42 \%$ of the total number of Engraulididae. In the first annual cycle, A. lepidentostole showed the most numerical abundance, contributing to $41 \%$ of the total fish catches. In the second annual cycle, A. januaria was the most abundant species contributing to $61 \%$ of the total number of fishes (Table 1).

Table 1. Percentage to the total numerical abundance by sites for Engraulididae in the Sepetiba Bay, from March 1996 to February 1998.

\begin{tabular}{lllllll}
\hline \multicolumn{7}{c}{ Sampling Sites } \\
\hline Species & 1 -Muriqui & 2-Itacuruçá & 3-Coroa Grande & 4-Sepetiba & 5 -Pedra de Guaratiba & Total \\
A. januaria & 3,2 & 14,8 & 2,4 & 96,0 & 38,4 & 42,0 \\
A. marinii & 11,6 & 0,2 & 0,0 & 0,5 & 0,2 & 1,4 \\
A. tricolor & 73,0 & 3,4 & 0,0 & 1,6 & 0,3 & 8,3 \\
A. lyolepis & 5,6 & 0,0 & 0,0 & 0,0 & 0,0 & 0,5 \\
A. lepidentostole & 2,0 & 27,4 & 48,8 & 0,5 & 35,7 & 22,9 \\
A. brevirostris & 4,4 & 54,0 & 48,8 & 1,3 & 25,4 & 24,9 \\
Total & $\mathbf{2 4 9}$ & $\mathbf{5 7 9}$ & $\mathbf{8 2}$ & $\mathbf{6 0 4}$ & $\mathbf{1 0 9 2}$ & $\mathbf{2 6 0 6}$ \\
\hline
\end{tabular}

Spatial and temporal distribution: Anchovies were present in all sampled sites (stations) of Sepetiba Bay with some species showing differences in abundances between sites, seasons and years (Fig. 2). Significant differences in numerical abundance were found between the sites for A. januaria, A. tricolor, A. lepidentostole and A. brevirostris according to the ANOVA F-values, and in biomass (weight) for A. januaria, A. tricolor e A. brevirostris.

Overall, A. tricolor predominated in the outer zone, mainly in Muriqui, while A. januaria, in the inner zone (Fig. 2). The species of Anchoviella occurred in all sites without presenting a clear differentiation in abundance between the outer and inner zones of the Bay. A. lyolepis and A. marinii showed low relative abundance, and occurred only in the first annual cycles, with the first species being limited to Muriqui and the second showing and ample distribution.

According to the SNK test, for spatial comparisons, A. tricolor (number and weight) was the only species which showed significant differences, predominating at Muriqui. Although the highly significant F-values from ANOVA, A. januaria did not show significant differences among sites according to SNK test.

\section{DISCUSSION}

The family Engraulididae was well represented in beach seines in the Sepetiba Bay, in both diversity and abundance. Six species were recorded, with one being the second most abundant in 1993/94 (Araújo et al., 1997). Four species of Anchoa and two of Anchoviella composed the Engraulididae in the Sepetiba Bay, with this diversity coinciding other coastal systems in the Southeast Brazil. Andreata et al. (1997) found only three species (A. januaria, A. tricolor, Anchoviella lepidentostole) in Rodrigo de Freitas Lagoon, the latter located in a very populated region, therefore limiting the number of species. Giannini \& Paiva-Filho (1995) found seven species (Anchoa filifera, A. januaria, A. lyoleps, A. marinii, A. tricolor, Anchoviellabrevirostris, A. lepidentostole, C. edentulus) in the sand beach in the São Paulo State. 


\begin{tabular}{|l|}
\hline \\
$\square$ A januaria \\
$\square$ A marinii \\
$\square \ldots$ A tricolor \\
$\ldots$ A. lyolepis \\
$5 \ldots$ A. lepidentostole \\
$\square$ A. brevirostris \\
\hline
\end{tabular}

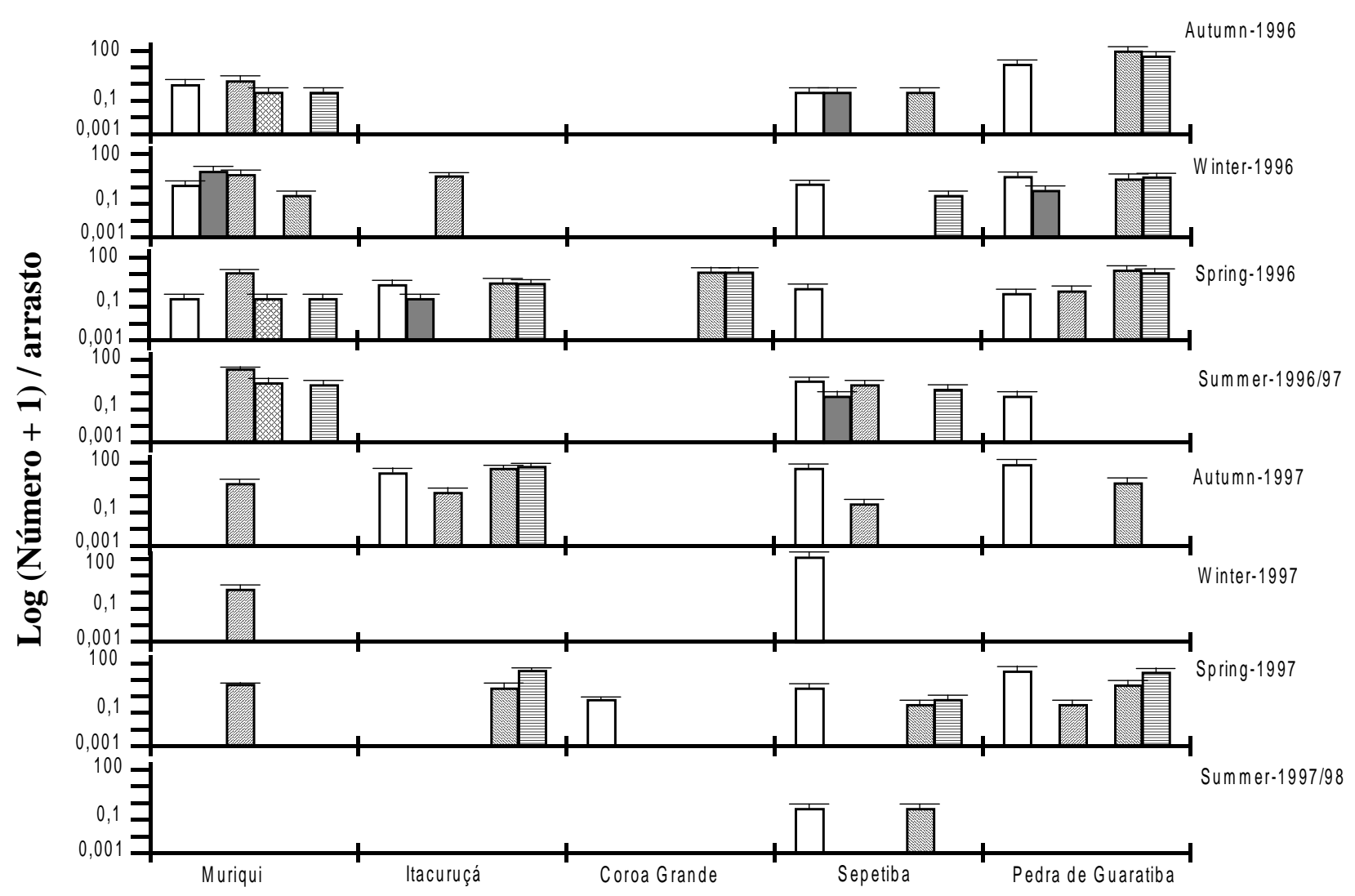

Figure 2. Spatial and temporal variations in numerical abundance $(\log x+1)$, of Engraulididae in the Sepetiba Bay, from Autumn 1996 to Summer 1997/98.

In South Brazil, Engraulidid diversity seemed to be lower when compared to Southeast. Weiss et al. (1976) found three species (Anchoa marinii, E. anchoita and Lycengraulis olidus) in the continental shelf between Santa Catarina and Rio Grande do Sul. Chao et al. (1982) reported only three species for the estuarine region of Lagoa dos Patos, Rio Grande do Sul and adjacent coastal zone (A. marini, E. anchoita and Lycengraulis sp). Ramírez et al. (1989) reported ten species (Anchoa argentivittata, A. curta, A. exigua, A. ischana, A. lucida, A. naso, A. panamensis, A. walkeri,
Anchovia macrolepidota, Cetengraulis mysticetus and Lycengraulis poeyi) with indication that in the Pacífico Ocean coast higher diversity of Engraulididae occurred than the Atlântico Ocean coast. In higher latitudes of temperate regions the diversity of this group of fish was less, with Cowan \& Shaw (1991) recording only four species in Lousiana coast (Anchoa hepsetus, A. mitchilli, A. nasuata and Anchoviella perfasciata) and Hart (1973) describing only Engraulis mordax for Canadá waters. 
A. januaria, in the sepetiba Bay, was the second fish species in numerical abundance in 1993/94 (Araújo et al., 1997), this was the second most abundant Engraulidid in 1996/97 anual cycle and the first in 1997/98. This species also has been reported by its high abundance in other coastal lagoon, such as Lagoa de Maracaibo, in Venezuela, represent $35.5 \%$ of larval and juveniles catches (Gonzalez-Bencomo, 1996). In the north hemisphere, this species seemed to give place to Anchoa parva in lower latitudes of Colômbia and Venezuela (Hernandez \& Leon, 1984; Osório \& Acero, 1996) and to Anchoa mitchilli in higher latitudes of Chesapeake Bay (latitude $38^{\circ} \mathrm{N}$ ), Laguna dos Terminos (latitude $18^{\circ} \mathrm{N}$ ) and in Lousiania estuaries (lat. $30^{\circ} \mathrm{N}$ ) (Coto et al., 1988; Rakocinski et al., 1992; Peebles et al, 1996).

Commercial anchovy fisheries are important contribution to economy of regions where they occur. In Brazil, fisheries are common in estuaries and lower reaches of rivers, such as Ribeira do Iguape river and São Vicente estuary in the São Paulo State, on Anchoviella lepidentostole, the only genera which showed eurihalinity, moving from the the estuary to lower reaches for spawning (Bendazoli et al.,1990; Paiva-Filho et al., 1986; 1990). In the Paraíba do Sul river an intensive fishery occurred on Anchoviella lepidentostole next to São Fidelis (Araújo, 1996).

High abundance of A. januaria in the inner zone of Sepetiba Bay could be associated with the occurrence sheltered areas where larvae would be more protected against predation and there has been more food availability. The sites of inner zone Pedra de Guaratiba and Praia de Sepetiba, where this species was more abundant, had been the regions relatively well protected because their position in the inner Bay where depth has been lower avoiding the majority of predators. The proximity of urban centers near to this sites also could contribute to high organic loads which could function of nutrient input for primary productivity fitoplancton and primary consumers zooplanctonic which are common prey for Engaulididae.

The spawning areas of this species is unknow in the studied area, although it would be common this genera to spawn in coastal adjacent areas, with eggs and larvae penetrating the semi-enclosed environments like bays and estuaries for early ground development. It was found that Anchoa mitchilli in the Chesapeake Bay, spawn in areas near to the sea limit and eggs and larvae move to the inner Bay looking for protection (Macgregor \&
Houde, 1996). A. mitchilli in Términos Lagoon, México also showed similar distribution pattern, with juveniles moving to the innermost area for feeding (Coto et al., 1988).

A. marinii in the Sepetiba Bay showed distribution limited to outer Bay near to the sea limit, where the salinity was higher. Low relative abundance of this species in Sepetiba Bay, a area of stable salinity around $29 \%$, might be due to the location of Rio de Janeiro near to the northern distribution limit for this species. According Figueiredo \& Menezes (1978), this species distributed from Cabo Frio to Argentina, which could explain their low abundance in the studied area.

In the Sepetiba Bay, A. tricolor was found only at Muriqui; nevertheless due to few number of individuals no clear inference could be drawn for this species about their distribution pattern. The great diversity of environments in which this species occurred, forming huge shoals ranging from mangles to sand beaches could suggest that fishes supported ample variations of temperture and salinity (Whitehead, 1977). Low abundance of this species restricted to outer Bay suggested the low occurrence and use of the Bay by A. tricolor.

A. lepidentostole is a anadrom species, therefore, is characterized by penetrating into estuaries and doing migrations to lower rivers' reaches where they spawn (Paiva-Filho et al., 1986; Bendazoli et al., 1990). It was not possible to find the spatial pattern for this species in Sepetiba Bay; in the first annual cycle of study the higher catches occurred in the inner Bay sites, while in the second at Itacuruça site located in the outer Bay. Bendazoli et al. (1990) observed that A. lepidentostole went up to Ribeira river for spawning, being caught in large amounts during Spring and Summer. Such fisheries are important commercial support for the human populations at Ribeira de Iguape region. Such migrations upriver could reach up to $140 \mathrm{~km}$ and the fish caught commonly shows ripe gonads (Carvalho, 1950).

Anchoviella brevirostris showed na spatial pattern of distribution very similar to A. lepidentostole. Figueiredo \& Menezes (1978) reported that such fishes were commonly found together in catches. Its distribution have been reported from the Guianas to Paraná State coast. 


\section{RESUMO}

A abundância relativa e distribuição espacial de juvenis de peixes da familia Engraulididae ocorrentes na Baía de Sepetiba, Rio de Janeiro, Brasil, foram estudadas visando determinar os padrões de uso da margem continental durante a fase inicial de vida. Dois ciclos anuais (Março1996 a Fevereiro-1997 e Março-1997 a Fevereiro1998) foram investigados através de um total de 120 amostragens de arrastos de praia, distribuídas em 5 locais de coleta na margem continental da Baía, duas delas situadas na zona mais interna e três na zona mais externa e próxima do limite com o mar. Foram identificados 6 espécies de Engraulididae, compreendendo dois gêneros: Anchoa januaria, Anchoa marinii, Anchoa tricolor, Anchoa lyplepis, Anchoviella lepidentostole e Anchoviella brevirostris, sendo a maioria das espécies representada por juvenis na fase inicial de vida. A. januaria, A. brevirostris, A. lepidentostole e A. tricolor, nesta ordem, foram as espécies de maior abundância numérica, enquanto A. tricolor e A. januaria, foram as de maior contribuição em peso, correspondendo em conjunto á aproximadamente $90 \%$ do total de peixes. Espacialmente, A. tricolor, A. lyolepis e A. marinii distribuiram-se na zona mais externa da Baía. A. januaria apresentou maior abundância na zona mais interna da Baía, enquanto as espécies do gênero Anchoviella distribuiram-se amplamente na Baía, não apresentando um padrão definido de ocorrência espacial. Sazonalmente, somente $A$. januaria, A. lepidentostole e A. brevirostris apresentaram um padrão definido, com maior abundância no Outono.

\section{REFERENCES}

Andreata, J. V. ; Marca, A. G. ; Soares, C. L. \& Santos, R. S. , 1997. Distribuição mensal dos peixes mais representativos da Lagoa Rodrigo de Freitas, Rio de Janeiro, Brasil. Revta bras. Zool. 14 (1): 121-134.

Araújo, F. G. , 1996. Composição e estrutura da Comunidade de peixes do médio e baixo Rio Paraíba do Sul, RJ. Rev. Brasil. Biol. , 56 (1): 111-126.

Araújo, F. G. ; Cruz-Filho, A G. ; Azevedo, M. C. C. ; Santos, A C. A.A \& Fernandes, L. A. M. 1997. Estrutura da comunidade de peixes jovens da margem continental da Baía de Sepetiba, RJ. Act. Biol. Leolpol. , 19 (1): 61-83.
Araújo, F. G. ; Cruz-Filho, A G. ; Azevedo, M. C. C. ; Santos, A C. A.A., 1998. Estrutura da comunidade de peixes demersais da Baía de Sepetiba, RJ. Rev. Brasil. Biol. , 58 (3): 417-430.

Barbiére, E.B. \& Kronemberger, D.M.P. 1994. Climatologia do Litoral Sul-Sudeste do Estado do Rio de Janeiro. Cad.Geoc., Rio de Janeiro. 12: 57-73.

Bendazoli, A. ; Rossi-Wongtschowski, C. L. D. B. ; GIAMAS, M. T. D. \& FROSCH, L. , 1990. A MANJUBA (Anchoviella lepidentostole) no Rio Ribeira de Iguape: biologia, comportamento e avaliação de estoque. IBAMA/IOUSP/IP-SA/SEMA. $116 \mathrm{p}$.

Carvalho, J. de P. , 1950. Engraulídeos brasileiros do gênero Anchoa. Bolm. Inst. Paul. Oceanogr. , São Paulo, 1 (2): 43-70.

Chao, L. N. ; Pereira, L. E. ; Vieira, J. P. ; Bemvenuti, M. A ; Cunha, L.P.R. 1982. Relação preliminar dos peixes estuarinos e marinhos da Lagoa dos Patos e região costeira adjacente, Rio Grande do Sul, Brasil. Atlântica, Rio Grande, 5(1): 67-75.

Coto, C. F. ; Luna, A. O. ; Calvo, A. L. ; García, F. Z. , 1988. Abundancia de algunas especies de Anchoas en la laguna de Términos (México), estimada a través de la captura de huevos. An. Inst. Ciênc. Del Mar y Limnol. Univ. Nal. Autón. México, 15 (1): 125-134.

Cowan Jr. , J. H. ; Shaw, R. F. , 1991. Ichthyoplankton off West Louisiana in Winter 1981-1982 and its Relatioship with Zooplankton Biomass. Contributions in Marine Science (1991), 32.

Figueiredo, J. L. \& N. A . Menezes, 1978. Manual de peixes marinhos do sudeste do Brasil, II- Teleostei (1) Museu de Zool. Univ. S. Paulo, 110

Giannini, R. \& Paiva- Filho, A. M. , 1995. Análise comparativa da ictiofauna da zona de arrebentação de praias arenosas do Estado de São Paulo, Brasil. Bolm. Inst. oceanogr. , S Paulo, 43 (2):141-152

Gonzalez-Bencomo, E. J. , 1996. Larvaland juvenile fish of the eastern of Lake Maracaibo, Venezuela. Bol. Cent. Invest. Biol. Maracaibo, 30 (1):45-76

Hart, J. L. , 1973. Pacific Fishes of Canada. Fisheries Research Board of Canada, Bulletin 180:103-105

Hernandez, B. J. P. ; Leon, J. R. , 1984. Analisis del Contenido estomacal y Habitos alimmenticios de la Camiguana Anchoa parva (Meek \& Hildebrand, 1923), (Pisces: Engraulidae) del Gorfo de Cariaco, Edo. Sucre, Venezuela. Bol. Inst. Oceanogr. Venezuela Univ. Oriente 23 (1,2):3-13 (1.984), 9 figs., 6 tabs.

Hildebrand, S. F. , 1963. Family Engraulidae. In Fishes of the Western North Atlantic. Mem. Sears. Fdn. Mar. Res. , New Haven, 1 (3):152-249.

Macgregor, J. M. ; Houde, E. D. , 1996. OnshoreOffshore pattern and variability in distribution and abundance of bay anchovy Anchoa mitchilli eggs and larvae in Cheasapeake Bay. Mar. Ecol. Prog. Ser. Vol 138: $15-25$. 
Moermond, T.C. , 1979. Resource partitioning: a dynamic competitive balance. P. 303-309. In: CLEPER, H. (ed.) Predator prey systems in fisheries management. Washington, Sport Fishing Institute. 504

Osorio, A. C. ; Acero, A. P. , 1996. Reproducción de Anchovia clupeoides y Anchoa parva (Pisces: Engraulidae) en dos ciénagas del Caribe Colombiano. Rev. Biol. Trop. 44(2): 781-793

Paiva-Filho, A. M. ; Giannini, R. ; Neto, F. B. R. , 1990. A pesca da manjuba Anchoviella lepidentostole (Engraulidae) no estuário de São Vicente, SP. Relat. Int. Inst. Ocanogr. Univ. S Paulo. 29: 1-6

Paiva-Filho, A. M. ; Zani Teixeira, M. L. \& Kihara, P. K. , 1986. Contribuição ao conhecimento da Biologia da manjuba, Anchoviella lepidentostole (FOWLER, 1911), no estuário de São Vicente, SP (Osteichthyes, Engraulidae). Bolm Inst. Oceanogr., S Paulo, 34: 7177

Peebles, E. B. ; Hall, J. R. ; Tolley, S. G. , 1996. Egg production by the bay anchovy Anchoa mitchilli in relation to adult and larval prey fields. Mar. Ecol. Prog. Ser. 131: 61-73
Rakocinski, C. F. ; Baltz, D. M. ; Fleeger, J. W. , 1992. Correspondence between environmental gradients and the community structure of marsh-edge fishes in a Louisiana estuary. Mar. Ecol. Prog. Ser., 80: 135148

Ramírez, C. A. R. ; Szelistowski, W. A. ; Lopez, S. M. I. , 1989. Spawning pattern and larval recruitment in Gulf of Nicoya anchovies (Pisces: Engraulidae). Rev. Biol. Trop. 1989. vol. 37(1): 55-62.

Sergipense, S. \& Sazima, I., 1988. Variações sazonais de ocorrência e tamanho em duas espécies de Engraulididae (Osteichthyes) na Baía de Sepetiba, Rio de Janeiro. Rev. Brasil. Biol. , 55 (3): 491-501.

Valentin, J. L. , 1994. Ressurgência: Fonte de vida dos oceanos. Ciência Hoje. 15(102): 19-25

Weiss, G. ; Souza, J. A. F. ; Santos, A. , 1976. Contribuição ao conhecimento do Ictioplancton marinho da plataforma sul do Brasil. Atlântica, Rio Grande, 1 (1/2): 7-78.

Whitehead, P. J. P. , 1977. Engraulidae. In FAO species identification sheets for fishery purposes. Wetern Central Atlantic (Fishing Area 31), Rome. 2 